\title{
Elastase と動脈硬化に関する研究*
}

一一実験的粥状動脈硬化および退縮に及ぼす Elastase の作用—

清 川 道 夫** 清 水 航 一** 岩 本 俊 彦***
海老原 隆 郎** 勝 沼 英 宇** 外 野 正 巳***

\section{I. 緒 言}

Baló および Banga') により膵蛋白分解酵素で ある elastase が大動脈 elastin を分解する作用が あると提唱されて以来, elastase と動脈硬化との 関係についての報告は数多い.

私達も, 以前より SD-SLC 系ラットを用いて cholesterol 含有動脈硬化食で飼育し, Vitamin $\mathrm{D}_{2}$ を負荷して惹起した実験的動脈硬化ラットの動脈 壁弾性線維に及ぼす elastase の作用について報告 している2).すなわち, elastaseには変性病的 elastin を分解し, 新たに elastin の合成および新 生促進作用が存在し, elastase が動脈壁弾性線維 の elastin 代謝を調節し, 抗動脈硬化作用を有す ることが推測されたため, 今回は elastase が粥状 硬化の退縮 regression に及ぼす影響について検討 した.

\section{II. 実験方法}

8 週齢の SD-SLC 系雄性ラットを使用, 全ラッ ト 6 週間 atherogenic diet で飼育すると同時に, 最初の 4 日間はVitamin $D_{2} 35$ 万単位 $/ \mathrm{kg}$ weight を olive oil に溶解し経口投与して動脈硬化を作 成した. 6 週目で 4 群に分け, regression control 群は normal diet 飼育に変更した R-N 群, normal diet とともに elastase 450 EL.U./kg/day を連日傍 腰筋に筋注した群を R-NE 群, disease control 群 は atherogenic diet を継続投与した R-A 群,

* 1982年 7 月, 第14回日本動脈硬化学会において発表 ** 東京医科大学老年病学教室

同 第二病理 atherogenic diet とともに elastase を投与した群 を R-AE 群とした. 各群 9, 12, 15 週目に屠殺し 大動脈組織標本を作成, HE 染色, Elastica Van Gieson 弾性線維染色，AMPS 染色をほどこし光 顕にて観察した (Table 1).

\section{III. 結 果}

\section{R-A 群, R-AE 群 9 週目の比較}

R-A 群， R-AE 群ともに粥状硬化像および石灰 沈着は同等に認められ肉眼的に有意差はなかった. 組織像でも両群ともに内膜から中膜にかけて泡沫 細胞が出現, 中膜全体にわたって石灰沈着を認め たが Elastica Van Gieson 染色では R-A 群に弾性 線維の断裂・走行異常が著明に認められる。一方 $\mathrm{R}-\mathrm{AE}$ 群では弾性線維が比較的良好に保たれてい た.

\section{R-N 群, R-NE 群 9 週目の比較}

正常食に変更した R-N 群と R-NE 群の HE 染 色では R-N 群は R-NE 群に比べ石灰沈着がやや 強いと思われるが有意差は認めず, Elastica Van Gieson 染色でも弾性線維の断裂・消失は R-N 群 に軽度認めるも両者間で大きな差は認めない。

\section{R-A 群, R-AE 群 12 週目の比較}

12 週目の R-A 群, R-AE 群は石灰化が強く, 大動脈起始部から弓部に顕著であるが，胸・腹部 大動脈における粥状硬化病巣は R-NE群に軽度 であり, 組織像では R-A 群により高度の粥状硬 化病変 - 石灰沈着を認め, 弾性線維の破壊も著し く, R-AE 群はそれに比べ粥状硬化・石扊沈着も 軽微な部位が多く, 弾性線維も良好に保たれ両者 間には明らかな差異を認めた。 
Table 1 Regression Studies of Elastase R-N : Atherogenic diet ( 6 weeks); Normal diet (Regression control)

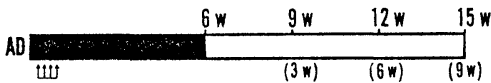

R-ME: Atherogenic diet ( 6 weeks) ; Normal diet + Elastase

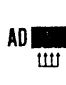

R-A : Atherogenic diet

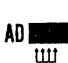

แt

R-AE: Atherogenic diet ( 6 weeks); Atherogenic diet + Elastase

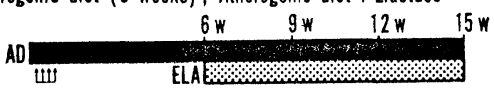

ND: Normal diet (CLEA JAPAN Inc.)

AD: Atherogenic diet

$\begin{array}{lr}\text { Cholesterol } & 2 \% \\ \text { Cholic acid } & 0.5 \% \\ \text { Lard } & 10 \% \\ \text { Cane Sugar } & 5 \% \\ \text { Me-thiouracil } & 0.2 \% \\ \text { Basal diet } & 82.3 \%\end{array}$

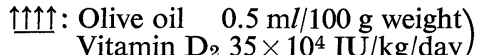
$\times 4$ days (per os)

ELA: Elastase 450 EL.U./kg/day (IM)

Table 2 Regression群間の硬化性病変の比較

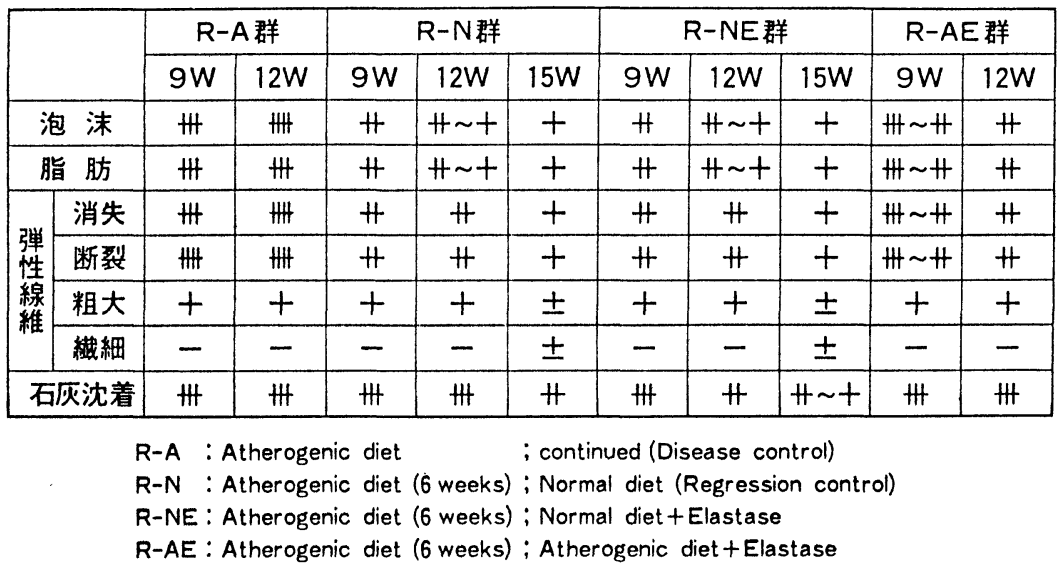

\section{R-N 群 12 週目と R-N 群 15 週目の比較}

$\mathrm{R}-\mathrm{N}$ 群においては，12 週，15 週とともに石灰 沈着・硬化性病変が強く残る部位もあるが，15週 目の方に硬化性病変の改善したと思われる部分が 多く, 弾性線維の破壊・蛇行もほぼ正常の形態を 取り戻している部分も多く, その改善が著しい.

\section{R-NE 群 12 週目, R-NE 群 15 週目の比較}

R-NE 群においてもまた R-N 群とほぼ同じよ うに12週目には所々に石灰沈着を残すものの，弾 性線維の走行も良く保たれ，15週目ではさらに改 善を認めた。

以上を総括すると R-N 群, R-NE 群両者間に 優位差はないが，12週目，15週目と経過を追うご とに改善を示し, 一方 R-A 群は経過に従い増覀 する. R-AE 群は R-A 群にくらべ 12 週目でかな り改善を認めた (Table 2).

\section{IV. 考案}

Elastase には, 䉼状動脈硬化病変の発生および 弾性線維の断裂に対して抑制効果がみられ，この 機序としては elastase が変性した病的弾性線維 elastin を分解すると同時に, 弾性線維の生合成を 促進するであろうという組織学的所見を得たのが 前回の実験報告である ${ }^{2)}$. さらに電顕学的所見で は, elastase 投与群は非投与群に比して中膜細胞 におけるミトコンドリア, 粗面小胞体の存在, 核お よび lysosome の変性像の減少, 弾性線維と思わ れた部位に多数の顆粒物質を認め, それに混入す る amorphous component, その周辺に microfibril の存在を認めたことから elastase には変性 elastin 分解と elastin 合成および新生促進を促す抗動脈 硬化作用があることを裏付けた ${ }^{3)}$. 
前実験の 6 週時で atherogenic diet 投与により atheroma が胸・腹部大動脈に惹起される成績を ふまえ, 今回 6 週目より正常食投与 (R-N 群), 正 常食プラス elastase 投与 (R-N 群), atherogenic diet 継続投与 (R-A 群), atherogenic diet プラス elastase 投与 (R-AE 群) の4つの群間の regression 実験による成績を報告した.

正常食投与群 (R-N 群) と正常食プラス elastase 投与群 (R-NE 群) はあまり差はないがともに15週 目で atheroma の所見は軽度で弾性線維の消失・ 断裂の程度が最も弱い。一方, atherogenic diet プラス elastase 投与群 (R-AE 群) は明らかに atherogenic diet のみの飼育群 (R-A 群) に比し弾 性線維 および 粥状硬化病変を抑制した成績から regression に対しては atherogenic diet から正常 食に変更することでも効果が得られた。

しかし，正常食投与群 (R-N 群) と正常食プラ ス elastase 投与群 (R-NE群)ではあまり差がみら れなかったのは，一度正常食で正常化した弾性線
維に対しては elastase が作用しないためと考えら れる。

これに対し atherogenic diet プラス elastase 投 与群 (R-AE 群) では elastase を使用しない atherogenic diet 投与群 (R-A 群) より明らかに䉼状硬 化および弾性線維の断裂は弱く, 初めより atherogenic diet で飼育した 6 週後の動脈硬化病変よ り軽度である点から elastase にも退縮効果のある ことが推定された。

\section{文献}

1) Baló, J. and Banga, T.: The elastolytic activity of panceatic extracts. Biochem. Jour., 46: 384-387 (1950).

2）清川道夫, 他: Elastase と動脈硬化に関する研究—— 実験的大動脈粥状動脈硬化および弾性線維に及ぼす 影響一一. 動脈硬化, 10: 401-403 (1982).

3) 岩本俊彦, 他: Elastase の実験的動脈硬化ラットに 及ぼす大動脈の電顕微細構造. 日本動脈硬化学会昭 和 56 年度冬季大会で発表 (投稿中). 


\title{
Summary
}

\section{Antiarteriosclerotic Action of Elastase}

\section{-With Special Reference to Its Effect on Regressin Activity of Arteriosclerosis-}

\author{
Michio Kiyokawa*, Koichi Shimizu*, Toshihiko Iwamoto*, Takao Ebihara*, \\ Hideyo Katsunuma* and Masami HoKano**
}

*Department of Geriatrics, Tokyo Medical College

**Department of Pathology, Tokyo Medical College

Since Baló and Banga found that elastase had an action of degrading elastin, many reports on the relationships between arteriosclerosis and elastase were published. Hall found that elastase had two component, one is elastoproteinase, which shows protein digesting activity, and the other, elastomucase which has lipolytic activity.

Previous study showed that elastase had an antiarterisoclerotic action in rat induced fed with atherogenic diet and vitamin $D_{2}$ for four days orally. The mechanism of antiarteriosclerotic action of elastase were assumed to be a regulating action of biosynthesis of elastin in the arterial wall.

In this paper, the results on regression of arteriosclerosis in rats were presented.

Fourty arteriosclerotic rats experimentally induced fed with atherogenic diet together with 4 days vitamin $D_{2}$ at weeks 7 were divided into 4 groups; (1) Group R-N fed with standard diet. (2) Group R-NE fed with standard diet and treated with elastase (I.M. 450 El.U/kg/day). (3) Group R-A fed with atherogenic diet continuously. (4) Group R-AE fed with atherogenic diet and treated with elastase continuously.

At 12 and 15 weeks during the experiment, the changes in aortic elastic fibers were determined in these four groups of rats. There were little changes between Group R-N and R-NE at week 12 , but when compared with the Group R-N and $\mathrm{R}-\mathrm{NE}$ at week 15 respectively, the latter group showed less fissure of elastic fibers. In sharp contrast to the Group R-A, Group R-AE revealed much less marked interstitial rarefaction and fissure of elastic fibers at 12 as well as 15 weeks, which suggests that elastase and standard diet could bring about an action of regressing experimental arteriosclerosis of rats induced fed with atherogenic diet and 4 days vitamin $\mathrm{D}_{2}$.

Key words: Experimental atherosclerosis, Elastase, Elastin, Elastic fibers, Regression. 